\title{
EFFECTIVENESS OF INTRAOSSEOUS INFILTRATION OF AUTOLOGOUS PLATELET-RICH PLASMA IN THE AREA OF THE BONE MARROW EDEMA IN OSTEOARTHRITIS OF THE KNEE JOINT
}

Lychagin AV, Garkavi AV, Islaieh OI $₫$, Katunyan PI, Bobrov DS, Yavlieva RH, Tselisheva EYu

I.M. Sechenov First Moscow State Medical University, Moscow, Russia

Osteoarthritis $(\mathrm{OA})$ affects both elderly people, for whom it is one of the main causes of disability, and people of active working age and is an urgent clinical and social problem of resistance of pain syndrome to therapy. The disease is characterized by both destruction of intra-articular and paraarticular structures, such as subchondral bone. While OA is an important sign of pathological changes believe the bone marrow edema (BME). This work examines the effect of BME on development osteoarthritis, and therapeutic approaches to the management of patients with OA. The aim of the study was to develop a method of treatment of BME in OA of the knee joint by locally intraosseous injection of autologous thrombotic-rich plasma (PRP) into the edema zone. In this study 17 patients with the diagnosis: Osteoarthritis II-IV Grade. according to the classification of Kellgren-Lawrence, in which areas of local inflammation in the form of BME were detected on MRI in the subchondral zone in accordance with the international classification of WORMS (Whole Organ Magnetic Resonance Imaging Score). The mean age of patients was $41,7 \pm 14,3$ years, 10 of them were women and 7 men. Patients were treated with autological platelet-rich plasma under $x$-ray control injected from extra-articular intraosseous access in the area of BME. Evaluation of effectiveness of treatment performed by VAS, WOMAC and KOOS scales, before the introduction of autoplasma, after 1 and 3 months after the start of treatment. Three months after the manipulation, there was a statistically significant decrease in the intensity of inflammatory syndrome: for WOMAC by $17.5 \%$, for KOOS by $19.4 \%$ and for VAS by $33,1 \%(p<0,01)$. Thus, the efficiency of intraosseous Infiltration of autologous platelet-rich plasma in the treatment of patients with OA, accompanied by edema of the bone marrow in the subchondral zone, was proved.

Keywords: bone marrow edema, osteoarthritis, autologous platelet-rich plasma, intraosseous Infiltration, quality of life

Author contribution: Lychagin AV and Islaieh OI — research planning, literature collection and analysis, data interpretation, draft preparation; Garkavi AV — research planning, data interpretation; Katunyan PI — research planning, draft preparation; Bobrov DS, Yavlieva RH and Tselisheva EYu — research planning.

Compliance with ethical standards: the study was approved by the local ethics committee of the Sechenov University (protocol № 06-18 dated June 06, 2018). All patients agreed to participate in the study in writing.

$\triangle$ Correspondence should be addressed: Osama I. Islaieh

Bolshoi Tishinsky Pereulok 26/15, Moscow, 123557; osaibso@yahoo.com

Received: 12.07.2019 Accepted: 26.07.2019 Published online: 20.08.2019

DOI: $10.24075 /$ brsmu.2019.053

\section{ЭФФЕКТИВНОСТЬ ВНУТРИКОСТНОГО ВВЕДЕНИЯ АУТОЛОГИЧНОЙ ОБОГАЩЕННОЙ ТРОМБОЦИТАМИ ПЛАЗМЫ В ЗОНУ ОТЕКА КОСТНОГО МОЗГА ПРИ ОСТЕОАРТРОЗЕ КОЛЕННОГО СУСТАВА}

\author{
А. В. Лычагин, А. В. Гаркави, О. И. Ислейих $џ$, П. И. Катунян, Д. С. Бобров, Р. Х. Явлиева, Е. Ю. Целищева
}

Первый Московский государственный медицинский университет имени И. М. Сеченова (Сеченовский Университет), Москва, Россия

\begin{abstract}
Остеоартроз (ОА) поражает как пожилых людей, для которых он одна из основных причин инвалидности, так и лиц трудоспособного возраста и является актуальной клинической и социальной проблемой ввиду устойчивости болевого синдрома к проводимой терапии. Заболеванию характерна деструкция внутрисуставных и параартикулярных структур, таких как субхондральная кость. При ОА важным признаком патологических изменений служит отек костного мозга (ОКМ). В работе рассмотрены вопросы влияния ОКМ на развитие гонартроза, а также терапевтические подходы к ведению пациентов с ОА. Целью исследования была разработка методики лечения ОКМ при ОА коленного сустава путем локального внутрикостного введения в зону отека аутологичной обогащенной тромбоцитами плазмы (PRP). Исследовали 17 пациентов с диагнозом “Остеоартроз II-IV ст.» по классификации Kellgren-Lawrence, у которых на MPТ в субхондральной зоне выявлены области локального воспаления в виде ОКМ в соответствии с международной классификацией WORMS. Средний возраст пациентов составил 41,7 \pm 14,3 лет. Пациентам внутрикостно из внесуставного доступа в зону ОКМ вводили аутологичную обогащенную тромбоцитами плазму под рентгеноскопическим контролем. Оценку эффективности лечения проводили по шкалам ВАШ, WOMAC и KOOS до введения аутоплазмы, через 1 и 3 месяца после начала лечения. Через 3 месяца после манипуляции отмечалось статистически значимое снижение показателей интенсивности воспалительного синдрома: по WOMAC на 17,5\%, KOOS на 19,4\% и по BAШ на 33,1\% (p < 0,01). Таким образом, доказана эффективность внутрикостного введения аутологичной обогащенной тромбоцитами плазмы в лечении пациентов с ОА, сопровождающимся ОКМ в субхондральной зоне.
\end{abstract}

Ключевые слова: отек костного мозга, остеоартроз, аутологичная обогащенная тромбоцитами плазма, внутрикостное введение, качество жизни

Информация о вкладе авторов: А. В. Лычагин и О. И. Ислейих — планирование исследования, подбор литературы, интерпретация данных, подготовка черновика рукописи; А. В. Гаркави - планирование исследования, интерпретация данных; П. И. Катунян - планирование исследования, подготовка черновика рукописи; Д. С. Бобров, Р. Х. Явлиева и Е. Ю. Целищева - планирование исследования.

Соблюдение этических стандартов: исследование одобрено локальным комитетом по этике ФГАОУ ВО Первый МГМУ имени И. М. Сеченова (протокол № 06-18 от 06 июня 2018 г.). Все пациенты подписали добровольное информированное согласие.

$\bowtie$ Для корреспонденции: Осама Ибрахим Ислейих ул. Большой Тишинский переулок, д. 26/15, г. Москва, 123557; osaibso@yahoo.com

Статья получена: 12.07.2019 Статья принята к печати: 26.07.2019 Опубликована онлайн: 20.08.2019

DOI: $10.24075 /$ vrgmu.2019.053

According to the $\mathrm{WHO}, 11$ to $13 \%$ of the world's population suffer from osteoarthritis $(\mathrm{OA})$. OA affects both the elderly, for whom it is one of the main causes of disability, and the working age people [1-4]. Peculiar to the disease are chronic pain, destruction and loss of articular cartilage, remodeling of subchondral bone, formation of osteophytes, inflammation of the synovial membrane of varying degree, involvement of both intraarticular and paraarticular structures in the pathological process [5].

For a long time, it was the articular cartilage that was believed to be the driver of OA development. However, in the last decade the role of the subchondral bone (SB) has been attracting attention both from the point of view of etiopathogenesis and 
that of its clinical significance in the processes [6]. It was proved that SC remodeling plays an important part in OA pathogenesis [7]. The changes therein can come first and trigger OA of they can be a consequence of the developing degenerative dystrophic processes [8-10]

An important sign of pathological changes in SC with OA in the background is the MRI-detected bone marrow edema (BME). This term was first registered in 1988; it is increasingly used to describe an MR signal alerting of an OA-associated pathology $[11,12]$. BME is usually found in the subchondral sclerosis zone, aggravated by the increased share of the bone tissue volume and trabecular layer compaction [13]. As OA advances, BME tends to grow, which is considered an important risk factor in the subsequent progressive destruction of articular structures $[2,14,15]$. BME and joint deformation were shown to be the predictors of OA transition to the rapid progression stage [4]. Moreover, focal cartilage lesions often develop next to BME, and the MR signal intensity typically reflects the degree of cartilage tissue destruction $[16,17]$. a number of researchers consider BME one of the reasons behind the associated severe pain. OA patients complaining about intense pain around the affected joint had a BME measuring over $1 \mathrm{sq} \mathrm{cm}$ (as detected by MRI) more often than those who did not report pain as severe $[14,18]$. Patients with BME were showing significant progression of cartilage destruction accompanied by pain [19]. Thus, BME can be considered a predictor of the onset of cartilage degradation and pain even before manifestation of all typical clinical symptoms of OA. At the same time, some researchers believe that BME can also be a sign of osteonecrosis, which causes pain at rest $[20,21]$.

Despite the increasing attention paid to the BME's influence on OA lately, a consensus has not yet been reached. Treating subchondral bone pathology in the context of a complex OA therapy is one of the most-discussed topics. When the nature of articular cartilage and subchondral bone interrelation was understood, the importance of changes in this bone became more apparent. The interrelation was called the osteochondral (functional) unit. It was shown that BME is closely associated with the progression of intraarticular structures degeneration and joint pains intensification. Thus, the likelihood of arthroplasty as the optimal therapy grows together with the expansion of BME [22, 23].

Genetic and histological analysis of the bone marrow samples taken from the affected zone revealed that pain linearly correlates not only with the OA progression status but also with changes in the subchondral BME microenvironment [24]. BME zones have shown to host intense metabolic activity that implies expression of genes involved in the inflammatory processes [24]. Thus, it is assumed that bone metabolism rate in a BME is high, as is the accumulation of cytokines and angiogenic factors, which drives growth of new vessels and nerve endings in this region [25].

There is a subchondroplasty technique applied to treat OA-associated bone and cartilage pathology that implies introducing calcium phosphate to the affected subchondral bone under arthroscopic control. a trial on 133 gonarthrosis patients that also had BME has proven the technique effective, although 2.5 years after the procedure $25 \%$ of them reported no improvements and agreed to joint replacement [23]. Another paper describes a trial of the same technique on 164 gonarthrosis patients that were recommended to have their joint replaced. After subchondroplasty, $70 \%$ of them reported significant improvement and decided to refuse the replacement [26].

Currently, a growing number of practitioners turn their attention to a group of techniques implying intraosseous administration of autologous platelet-rich plasma [27-29].
The mechanisms behind the good results registered after injection of autologous platelet-rich plasma (PRP) are still being investigated, however, its anti-inflammatory and regenerative effects are no longer called into question. in this connection, it seems promising to seek development of an OA therapy that would revolve around administering PRP to the BME locus.

This study aimed to develop a PRP therapy against OAassociated BME that implies local intraosseous injections into the edema zone.

\section{METHODS}

The study involved 17 patients (41,7 \pm 14,3 years), 15 of them with grade II-IV knee OA (Kellgren-Lawrence classification) concomitant with MRI-detected BME primarily located in the medial (inner) parts of the knee joint [30]. Inclusion criteria: patients of both sexes in age from 40 to 80 years; predominance of the knee joint arthrosis, joint pain score more than 3 points on VAS; radiological 2 and 4 degrees of the disease severity according to I. Kellgren and I. Lawrence classifications with bone marrow edema in the subchondral zone; body mass index 20-33; opportunity for observation during the entire study period; mental adequacy, ability and willingness to cooperate and implement the doctor's recommendations. Exclusion criteria: bilateral arthrosis of the knee joints with synovitis; body mass index > 33; polyarthritis; severe limb deformation - varus curvature of the diaphysis more than $4^{\circ} \mathrm{C}$ and valgus - more than $16^{\circ} \mathrm{C}$; arthroscopy less than 1 year before treatment; intraarticular injections of hyaluronic acid over the past 6 months; systemic autoimmune diseases; poorly controlled diabetes mellitus (glycosylated hemoglobin above 9\%); blood diseases (coagulopathy, anemia with $\mathrm{HB}<90$ ); ongoing immunosuppressive therapy, treatment with warfarin or other anticoagulants; treatment with corticosteroids for 6 months before inclusion in the study; patient refusal from further participation in the study; identification of objective contraindications to surgery; lack of the possibility of dynamic monitoring and control during the established period.

The duration of the disease ranged from 1 to 9 years $(5,2 \pm 4,5)$. The patients were diagnosed with OA based on their complaints, history and clinical-radiological examination. All patients had their knee joints $\mathrm{x}$-rayed in two projections, anteroposterior and lateral, with tibia flexed at 30 (Table1).

MRI provided the data needed to evaluate the condition of the subchondral zone and BME in all patients. We used WORMS (Whole Organ Magnetic Resonance Imaging Score) to describe the bone marrow edema. The Score is designed to assess signal intensity on T2-weighted images [2]. The lesions were evaluated in points; we measured the maximum diameter of the edemas using RadiAnt DICOM Viewer 4.6.9 (64-bit) software (Medixant; France). Table 2 contains the diagnosis criteria. Figures 1 and 2 are tomograms depicting severe BME in some of the patients participating in the study.

Upon admission, all patients had their pain level evaluated with the help of VAS and filled the WOMAC and KOOS questionnaires [31-33]. The values of the same indicators were registered further on, in 1 and 3 months after the studied procedure.

\section{PRP preparation and method description}

We used a Regenlab PRP kit (REGEN ACR technology, 2011, Switzerland) to prepare PRP injections. The kit allows making a preparation that persists for a specific period of time after intraosseous administration. We distributed $30 \mathrm{ml}$ of 
autologous venous blood into three tubes: two REGEN BCT tubes to prepare autologous platelet-rich plasma and one REGEN ATS tube to obtain autologous thrombin serum used to activate the preparation (step 1). All tubes were centrifuged for 5 minutes at $3100 \mathrm{rpm}$ (step 2). Then, under sterile conditions, we mixed PRP from REGEN BCT and autologous thrombin serum from REGEN ATS in a syringe at 10:1 ratio (step 3) (Fig. 2). The PRP was injected into the BME zone as identified on the T2-weighted images, i.e. in the medial or lateral condyle of femur or tibia. For the manipulation, the patients were put on to the operating table, supine, under the influence of intravenous anesthesia (step 4) (Fig. 2).

The preparation was administered through a stylet with a 13 gauge mandrin (Stryker, USA); the process was monitored with the help of an electron-optical converter (EOC). The lesion received $5 \mathrm{ml}$ of the preparation through the needle that reached it (Fig. 3).

For the days following the procedure, the patients were recommended to apply cold locally, limit loads for up to 1 week, restrain from increased loads for up to 2 weeks, take $4 \mathrm{~g}$ of paracetamol a day (orally) if in pain. No selective non-steroidal anti-inflammatory drugs were used.

Statistica 13.3 software (StatSoft; USA) enabled statistical analysis of the data.
RESULTS

According to MRI, 2 patients had minimal BME, in 7 patients the edema was moderate and in 8 it was qualified as severe (Fig. 4).

After PRP administration, the pain, as measured with VAS, subsided significantly over time. Before the treatment, it was identified as "severe" (51.4 \pm 6.9 points); 1 month after, the score decreased by 36.4 points, which corresponds to "minor" $(15.0 \pm 8.3, p<0,01)$, and 3 months later the value was $18.3 \pm 11.6$ points, $(p<0.01)$, which is also within the "minor" range (Fig. 5).

WOMAC figures also reflect significant improvement of the indicators. The average score (summed) at admission was $57.38 \pm 12.85$ points, 1 month after drug administration $76.45 \pm 5.91$ points $(p<0.01)$, and after 3 months it reached $75.33 \pm 8.41(p<0.01)$ (Fig. 5).

KOOS figures followed the same pattern: the average score at admission was $52.78 \pm 13.38$ points, a month after PRP injection $-72.00 \pm 7.35$ points $(p<0.01)$, and 3 months later it reached $72.13 \pm 8.50$ points $(p<0.01)$ (Fig. 5).

Since KOOS includes 5 subscales that consider various aspects of the knee joint condition, it is of interest to evaluate them individually (Table 3). Relative to the beginning of the

Table 1. The patients

\begin{tabular}{|c|c|c|}
\hline \multirow{2}{*}{ Gender (number of patients) } & Female & $10(58.8 \%)$ \\
\hline & Male & $7(41.2 \%)$ \\
\hline \multicolumn{2}{|l|}{ Average age (years) } & $41.7 \pm 14.3$ \\
\hline \multicolumn{2}{|l|}{ Knee joint disease duration (years) } & $5.2 \pm 4.5$ \\
\hline \multicolumn{2}{|c|}{ Average time under medical supervision (months) } & $5.5 \pm 2.5$ \\
\hline Affected joint (amount) & One side & $17(100 \%)$ \\
\hline \multirow{4}{*}{ Kellgren-Lawrence grade based on x-ray } & 1 & 0 \\
\hline & II & $5(29.4 \%)$ \\
\hline & III & $10(58.8 \%)$ \\
\hline & IV & $2(11.8 \%)$ \\
\hline
\end{tabular}

Table 2. WORMS diagnosis criteria

\begin{tabular}{|l|c|c|}
\hline \multicolumn{1}{|c|}{ BME degree } & Lesion diameter (mm) & WORMS score \\
\hline None & $<5$ & 0 \\
\hline Minimal & $5-20$ & 1 \\
\hline Moderate & $>20$ & 2 \\
\hline Severe & 3 & 3 \\
\hline
\end{tabular}

A

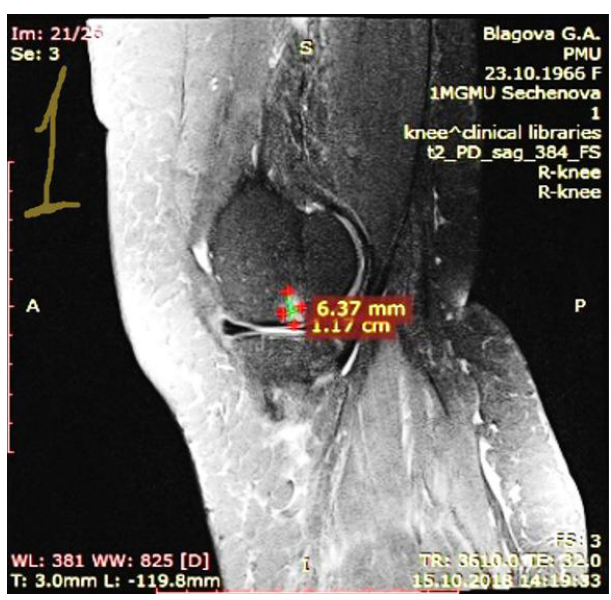

B

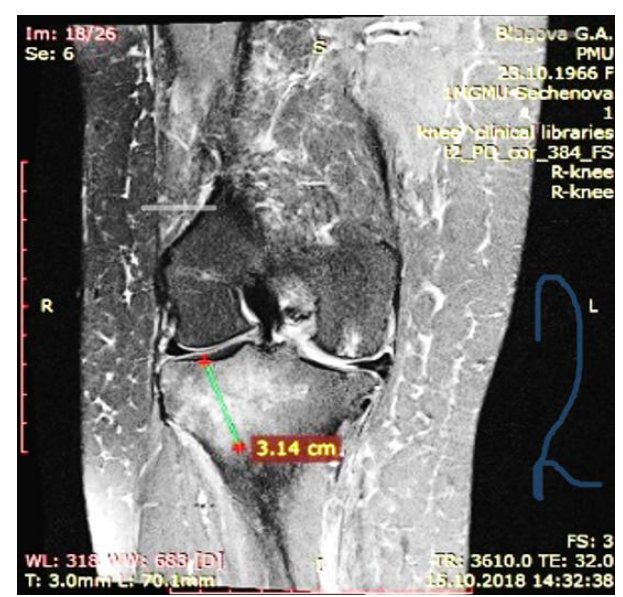

Fig. 1. Measuring the BME with the help of RadiAnt DICOM Viewer 4.6.9 (64-bit), WORMS. A. BME in the lateral condyle of the femur, size 1.17 cm. B. BME in the medial condyle of the tibia, size $3.14 \mathrm{~cm}$ 
treatment, all indicators have shown significant positive dynamics. It should be noted that the most pronounced improvement in the average values was recorded in the Sport and Recreation Function (from $25.83 \pm 21$ to $53.33 \pm 28.86$ ) and the Quality of Life (from 24.0818 .39 to 54.18 21.48) subscales by the third month. The pain subsided by the first month and then increased slightly by the third months but still remained significantly less intense.

It is important to note that the majority of KOOS subscales, as well as VAS and WOMAC, revealed that the improvement peaks 1 month after administration of the preparation, and by the third month the average values deteriorate slightly, although the change was not always significant.

\section{DISCUSSION}

The intraosseous subchondral PRP injection technique we developed is a minimally invasive and affordable modality to treat gonarthrosis with BME. The PRP preparation made with the Regenlab PRP kit offers a prolonged therapeutic effect. Previously, it was shown that BME is a zone of high bone metabolism and accumulation of cytokines and angiogenic factors, which is essentially translates into local inflammation $[24,25]$. The improvement of the patients' condition after administration of PRP supports the theory that such plasma produces a pronounced anti-inflammatory effect when applied topically. Despite the fact that PRP contains angiogenic and

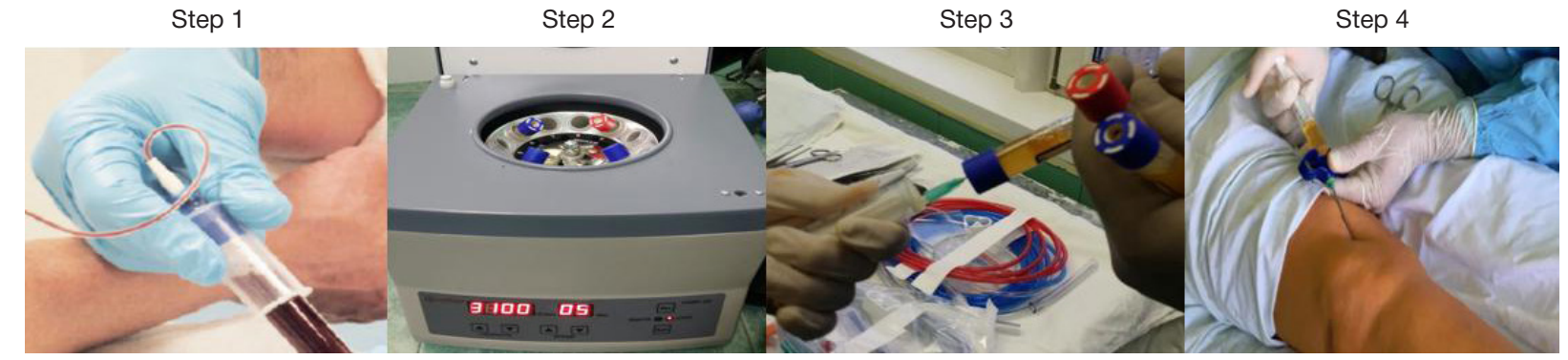

Fig. 2. Preparation of PRP. 1: Blood collection. 2: Centrifugation. 3: Mixing (10:1 ratio). 4: Injection

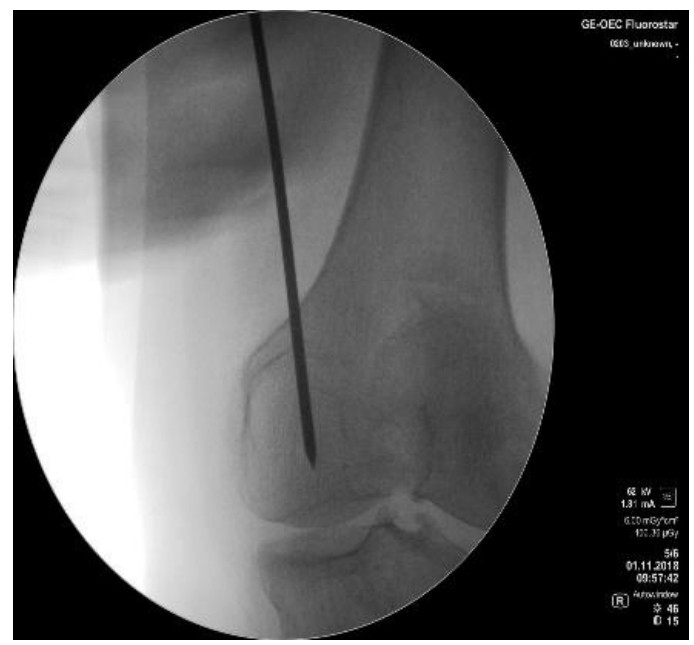

Fig. 3. EOC-controlled administration of PRP into the BME zone, medial condyle of the femur. EOC image: needle in the femur's medial condyle

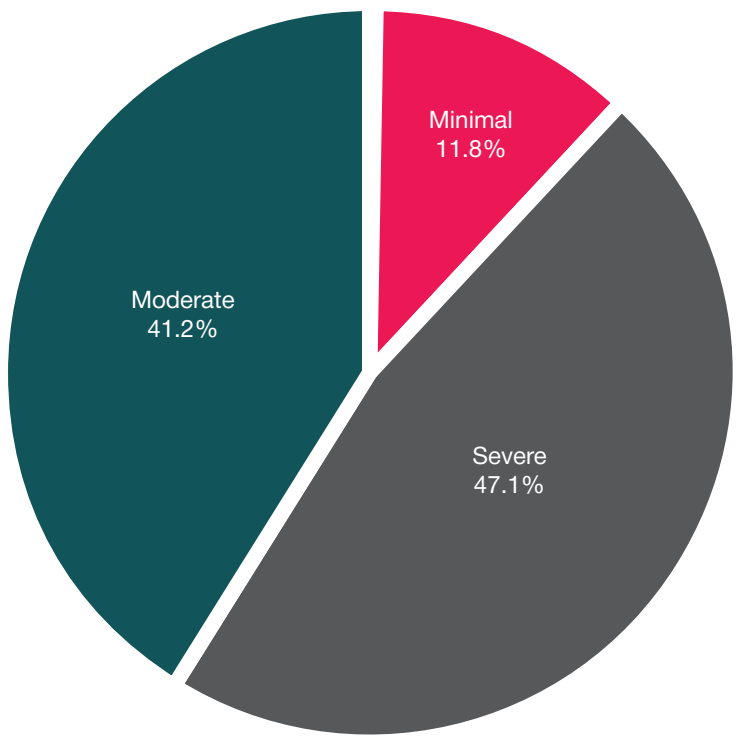

Fig. 4. Patients by BME severity, WORMS 


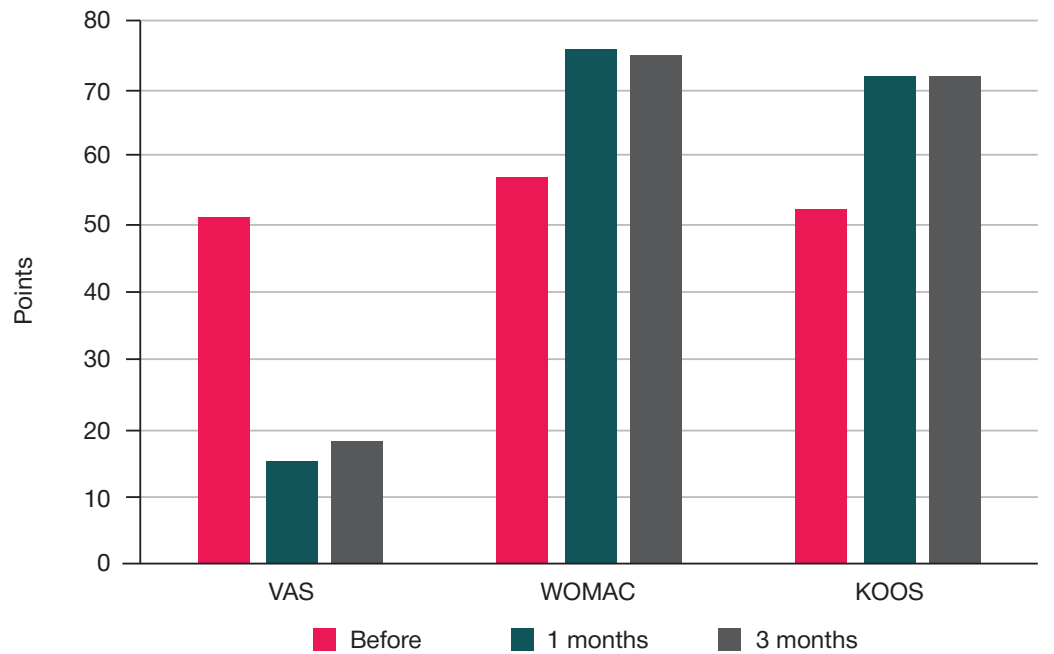

Fig. 5. Dynamics of the average values, VAS, WOMAC and KOOS. 17 knee OA patients were injected PRP in the BME zone. Their condition was assessed before injection and 1 and 3 months after treatment.

Table 3. Functional scale, KOOS subscales

\begin{tabular}{|l|c|c|c|}
\hline & Before & 1 month after treatment & 3 months after treatment \\
\hline Symptoms & $62.85 \pm 10.28$ & $74.28 \pm 10.53^{*}$ & $71.43 \pm 6.18^{*}$ \\
\hline Pain & $53.70 \pm 7.18$ & $73.40 \pm 11.87^{\star}$ & $70.36 \pm 12.52^{*}$ \\
\hline Activites of Daily Living & $53.36 \pm 15.41$ & $58.33 \pm 19.66^{*}$ & $74.51 \pm 4.24^{*}$ \\
\hline Sports and Recreation & $25.83 \pm 21$ & $40.62 \pm 23.30^{*}$ & $53.33 \pm 28.866^{*}$ \\
\hline Quality of Life & $24.08 \pm 18.39$ & $72.00 \pm 7.35^{*}$ & $72.13 \pm 8.50$ * \\
\hline Final index & $52.78 \pm 13.38$ & $78^{*}$ \\
\hline
\end{tabular}

Note: * - statistically significant change of the value compared to the initial measurements, $p<0.01$.

profibrotic growth factors, there was not reported a single case of aggravation.

The data we obtained in the context of this research effort are largely consistent with those of other authors who injected PRP intraosseously to treat gonarthrosis [27-29]. One of the papers describes treating 14 gonarthrosis patients (severe condition) with three intraarticular injections of $8 \mathrm{ml}$ of PRP in combination with subchondral intraosseous injections of $5 \mathrm{ml}$ of PRP (delivered to the medial tibial condyle and the medial condyle of the femur); after 6 months, all patients reported less pain and improved KOOS scores, which echoes our results [29]. In our case, the drug was administered intraosseously, once, and the clinical improvement was recorded 3 months earlier.

Nevertheless, it must be recognized that by the third month the achieved effect fades, although clinical tests still show that the improvement is significant.

The most pronounced improvements, which were recorded in the Sport and Recreation Function and the Quality of Life subscales, probably result from the emotional state of the patients who felt the positive effect of the treatment; thus, it should be monitored individually and with other measurement techniques.

\section{CONCLUSIONS}

II-IV grade OA, as defined by the Kellgren-Lawrence system, is aggravated by an MRI-detectable subchondral BME lesions, which are part of the disease pathogenesis contributing to its further progression and causing pain. Autologous platelet-rich plasma injected into the BME lesion produces a pronounced and persistent positive effect, alleviating pain and improving function of the affected joint; the effect lasts for at least 3 months.

Further investigation of the gonarthrosis-associated BME treatment method that implies use of PRP is an important task for modern orthopedics with considerable promise in the view of improvements registered in patients and the data on the role played by the osteochondral functional unit in the pathological process.

\section{References}

1. Felson DT, McLaughlin S, Goggins J, LaValley MP, Gale ME, Totterman S, et al. Bone marrow edema and its relation to progression of knee osteoarthritis. Ann Intern Med. 2003; (139): 330-6.

2. Kazakia GJ, Kuo D, Schooler J, Siddiqui S, Shanbhag S, Bernstein G et al. Arthritis Research \& Therapy. 2013; (15): 11-2.

3. Meizer R, Radda C, Stolz G, Kotsaris S, Petje G, Krasny C, et al. $\mathrm{MRI}$-controlled analysis of 104 patients with painful bone marrow edema in different joint localizations treated with the prostacyclin

analogue iloprost. Wien Klin Wochenschr. 2005; (117): 278-86.

4. Zajceva EM, Smirnov AV, Alekseeva I. Ocenka mineral'noj plotnosti kostnoj tkani subhondral'nyh otdelov bedrennoj i bol'shebercovoj kostej pri gonartroze. Nauchno-prakticheskaja revmatologija. 2005; (1): 27-30.

5. Felson DT. An update on the pathogenesis and epidemiology of osteoarthritis. Radiol Clin North Am. 2004; (42): 1-9.

6. Alekseeva LI, Zajceva EM. Rol' subhondral'noj kosti pri osteoartroze. 
NII revmatologii RAMN, Moskva. Nauchno-prakticheskaja revmatologija. 2009; (4): 43-8.

7. Delgado D, Garate A, Vincent H, Bilbao AM, Patel R, Fiz N, at al. Current concepts in intraosseous Platelet-Rich Plasma injections for knee osteoarthritis. Journal of Clinical Orthopaedics and Trauma. 2019; (10): 36-4.

8. Roemer FW, Frobell R, Hunter DJ, Crema MD, Fischer W, Bohndorf K, et al. MRI-detected subchondral bone marrow signal alterations of the knee joint: terminology, imaging appearance, relevance and radiological differential diagnosis. Osteoarthritis Cartilage. 2009; (17): 1115-31.

9. Roemer FW, Neogix T, Nevittk MC, Felsonx DT, Zhux Y, Zhangx $Y$, et al. Subchondral bone marrow lesions are highly associated with and predict subchondral bone attrition longitudinally. the MOST study Osteoarthritis and Cartilage. 2010; (18): 47-53.

10. Sowers MF, Hayes C, Jamadar D, Capul D, Lachance L, Jannausch M, et al. Magnetic resonance-detected subchondral bone marrow and cartilage defect characteristics associated with pain and X-raydefined knee osteoarthritis. Osteoarthritis and Cartilage. 2003; (6): 387-393.

11. Wilson AJ, Murphy WA, Hardy DC, Totty WG. Transient osteoporosis: transient bone marrow edema? Radiology. 1988; (167): 757-760.

12. Lecouvet FE, van de Berg BC, Maldague BE, Lebon CJ, Jamart J, Saleh $\mathrm{M}$, et al. Early irreversible osteonecrosis versus transient lesions of the femoral condyles: prognostic value of subchondral bone and marrow changes on MR imaging. AJR Am J Roentgenol. 1998; (170): 71-7.

13. Hunter DJ, Gerstenfeld L, Bishop G, Davis AD, Mason ZD, Einhorn TA, et al. Bone marrow lesions from osteoarthritis knees are characterized by sclerotic bone that is less well mineralized. Arthritis Res Ther. 2009; (11): 11.

14. Manicourt DH, Brasseur JP, Boutsen Y, Depreseux G, Devogelaer JP. Role of alendronate in therapy for posttraumatic complex regional pain syndrome type I of the lower extremity. Arthritis Rheum. 2004; (50): 3690-97.

15. Pelletier JP, Raynauld JP, Berthiaume MJ, Abram F, Choquette D, Haraoui B, et al. Risk factors associated with the loss of cartilage volume on weight-bearing areas in knee osteoarthritis patients assessed by quantitative magnetic resonance imaging: a longitudinal study. Arthritis Research and Therapy. 2007; (4): 74.

16. Zhao J, Li X, Bolbos RI, Link TM, Majumdar S. Longitudinal assessment of bone marrow edema-like lesions and cartilage degeneration in osteoarthritis using 3 T MR T1rho quantification. Skeletal Radiol. 2010: (39): 523-31.

17. Carrino JA, Blum J, Parellada JA, Schweitzer ME, Morrison WB. $\mathrm{MRI}$ of bone marrow edema-like signal in the pathogenesis of subchondral cysts. Osteoarthritis Cartilage. 2006; (14): 1081-15.

18. Peterfy CG, Guermazi A, Zaim S, Tirman PF, Miaux Y, White D, et al. Whole-Organ Magnetic Resonance Imaging Score (WORMS) of the knee in osteoarthritis. Osteoarthritis and Cartilage. 2004; 12 (3): 177-90.

19. Wluka AE, Hanna F, Davies-Tuck M, Wang Y, Bell RJ, Davis SR, et al. Bone marrow lesions predict increase in knee cartilage defects and loss of cartilage volume in middle-aged women without knee pain over 2 years. Ann Rheum Dis. 2009; (68): 850-5.

20. lida $S$, et al. Correlation between bone marrow edema and collapse of the femoral head in steroid-induced osteonecrosis. AJR. American Journal of Roentgenology. 2000; 174 (3): 735-43.

21. Ito $\mathrm{H}$, Matsuno $\mathrm{T}$, Minami $\mathrm{A}$. Relationship between bone marrow edema and development of symptoms in patients with osteonecrosis of the femoral head. AJR. American Journal of Roentgenology. 2006; 186 (6): 1761-70.

22. Perry T, O'Neill T, Parkes M, Felson DT, Hodgson R, Arden NK. Bone marrow lesion type and pain in knee osteoarthritis. Ann Rheum Dis. 2018; (77): 1145.

23. Tanamas SK, Wluka AE, Pelletier JP, Pelletier JM, Abram F, Berry PA, et al. Bone marrow lesions in people with knee osteoarthritis predict progression of disease and joint replacement. A longitudinal study Rheumatology. 2010; (49): 2413-19.

24. Berger CE, Kroner AH, Minai-Pour MB, Ogris E, Engel A. Biochemical markers of bone metabolism in bone marrow edema syndrome of the hip. Bone. 2003; (33): 346-51.

25. Kuttapitiya A, Assi L, Laing K, Hing C, Mitchell P, Whitley G, et al. Microarray analysis of bone marrow lesions in osteoarthritis demonstrates upregulation of genes implicated in osteochondral turnover, neurogenesis and inflammation. Ann Rheum Dis. 2017; 76 (10): 1764-73.

26. Astur DC, de Freitas EV, Cabral PB, Morais CC, Pavei BS, Kaleka CC, et al. Evaluation and management of subchondral calcium phosphate injection technique to treat bone marrow lesion Cartilage. 2018; (10): 1177.

27. Su K, Bai Y, Wang J, Zhang H, Liu H, Ma S. Comparison of hyaluronic acid and PRP intra-articular injection with combined intra-articular and intraosseous PRP injections to treat patients with knee osteoarthritis. 2018; (37): 1341-50.

28. Fiz N, Pérez JC, Guadilla J, Garate A, Sánchez P, Padilla S, et al. Intraosseous Infiltration of Platelet-Rich Plasma for Severe Hip Osteoarthritis. 2017; 19 (6): 821-5.

29. Sánchez M, Anitua E, Delgado D, Sanchez P, Prado R, Goiriena JJ, et al. A new strategy to tackle severe knee osteoarthritis: Combination of intra-articular and intraosseous injections of Platelet Rich Plasma. Expert Opinion on Biological Therapy. 2016; (10): 15-7.

30. Kellgren JH, JeVrey M, Ball J. Atlas of standard radiographs. Vol 2. Oxford: Blackwell Scientific, 1963.

31. Roos E, Lohmander L. The Knee injury and Osteoarthritis Outcome Score (KOOS): from joint injury to osteoarthritis. Health and Quality of Life Outcomes. 2003; 1 (1): 64-72.

32. Marot V, Murgier J, Carrozzo A, Reina N, Monaco E, Chiron P et al. Determination of normal KOOS and WOMAC values in a healthy population. Knee Surgery, Sports Traumatology, Arthroscopy. 2018; 27 (2): 541-8.

33. Hawker G, Mian S, Kendzerska T, French M. Measures of adult pain: Visual Analog Scale for Pain (VAS Pain), Numeric Rating Scale for Pain (NRS Pain), McGill Pain Questionnaire (MPQ), Short-Form McGill Pain Questionnaire (SF-MPQ), Chronic Pain Grade Scale (CPGS), Short Form-36 Bodily Pain Scale (SF. Arthritis Care \& Research. 2011; 63 (S11): S240-52.

\section{Литература}

1. Felson DT, McLaughlin S, Goggins J, LaValley MP, Gale ME, Totterman S, et al. Bone marrow edema and its relation to progression of knee osteoarthritis. Ann Intern Med. 2003; (139): 330-6.

2. Kazakia GJ, Kuo D, Schooler J, Siddiqui S, Shanbhag S, Bernstein G et al. Arthritis Research \& Therapy. 2013; (15): 11-2.

3. Meizer R, Radda C, Stolz G, Kotsaris S, Petje G, Krasny C, et al. $\mathrm{MRI}$-controlled analysis of 104 patients with painful bone marrow edema in different joint localizations treated with the prostacyclin analogue iloprost. Wien Klin Wochenschr. 2005; (117): 278-86.

4. Зайцева Е. М. Оценка минеральной плотности костной ткани субхондральных отделов бедренной и большеберцовой костей при гонартрозе. Научно-практическая ревматология. 2005; (1): 27-30.

5. Felson DT. An update on the pathogenesis and epidemiology of

osteoarthritis. Radiol Clin North Am. 2004; (42): 1-9.

6. Алексеева Л. И., Зайцева Е. М. Роль субхондральной кости при остеоартрозе. НИИ ревматологии РАМН. Научнопрактическая ревматология. М., 2009; (4): 43-8.

7. Delgado D, Garate A, Vincent H, Bilbao AM, Patel R, Fiz N, at al. Current concepts in intraosseous Platelet-Rich Plasma injections for knee osteoarthritis. Journal of Clinical Orthopaedics and Trauma. 2019; (10): 36-4.

8. Roemer FW, Frobell R, Hunter DJ, Crema MD, Fischer W, Bohndorf K, et al. MRI-detected subchondral bone marrow signal alterations of the knee joint: terminology, imaging appearance, relevance and radiological differential diagnosis. Osteoarthritis Cartilage. 2009; (17): 1115-31.

9. Roemer FW, Neogix T, Nevittk MC, Felsonx DT, Zhux Y, Zhangx Y, 
et al. Subchondral bone marrow lesions are highly associated with and predict subchondral bone attrition longitudinally. The MOST study Osteoarthritis and Cartilage. 2010; (18): 47-53.

10. Sowers MF, Hayes C, Jamadar D, Capul D, Lachance L, Jannausch M, et al. Magnetic resonance-detected subchondral bone marrow and cartilage defect characteristics associated with pain and X-ray-defined knee osteoarthritis. Osteoarthritis and Cartilage. 2003; (6): 387-393.

11. Wilson AJ, Murphy WA, Hardy DC, Totty WG. Transient osteoporosis: transient bone marrow edema? Radiology. 1988; (167): 757-760.

12. Lecouvet FE, van de Berg BC, Maldague BE, Lebon CJ, Jamart J, Saleh $\mathrm{M}$, et al. Early irreversible osteonecrosis versus transient lesions of the femoral condyles: prognostic value of subchondral bone and marrow changes on MR imaging. AJR Am J Roentgenol 1998; (170): 71-7.

13. Hunter DJ, Gerstenfeld L, Bishop G, Davis AD, Mason ZD, Einhorn TA, et al. Bone marrow lesions from osteoarthritis knees are characterized by sclerotic bone that is less well mineralized. Arthritis Res Ther. 2009; (11): 11.

14. Manicourt DH, Brasseur JP, Boutsen Y, Depreseux G, Devogelaer JP. Role of alendronate in therapy for posttraumatic complex regional pain syndrome type I of the lower extremity. Arthritis Rheum. 2004; (50): 3690-97.

15. Pelletier JP, Raynauld JP, Berthiaume MJ, Abram F, Choquette D, Haraoui B, et al. Risk factors associated with the loss of cartilage volume on weight-bearing areas in knee osteoarthritis patients assessed by quantitative magnetic resonance imaging: a longitudinal study. Arthritis Research and Therapy. 2007; (4): 74.

16. Zhao J, Li X, Bolbos RI, Link TM, Majumdar S. Longitudinal assessment of bone marrow edema-like lesions and cartilage degeneration in osteoarthritis using 3 T MR T1rho quantification. Skeletal Radiol. 2010: (39): 523-31.

17. Carrino JA, Blum J, Parellada JA, Schweitzer ME, Morrison WB. $\mathrm{MRI}$ of bone marrow edema-like signal in the pathogenesis of subchondral cysts. Osteoarthritis Cartilage. 2006; (14): 1081-15.

18. Peterfy CG, Guermazi A, Zaim S, Tirman PF, Miaux Y, White D, et al Whole-Organ Magnetic Resonance Imaging Score (WORMS) of the knee in osteoarthritis. Osteoarthritis and Cartilage. 2004; 12 (3): 177-90.

19. Wluka AE, Hanna F, Davies-Tuck M, Wang Y, Bell RJ, Davis SR, et al. Bone marrow lesions predict increase in knee cartilage defects and loss of cartilage volume in middle-aged women without knee pain over 2 years. Ann Rheum Dis. 2009; (68): 850-5.

20. lida $S$, et al. Correlation between bone marrow edema and collapse of the femoral head in steroid-induced osteonecrosis. AJR. American Journal of Roentgenology. 2000; 174 (3): 735-43.

21. Ito $H$, Matsuno $T$, Minami $A$. Relationship between bone marrow edema and development of symptoms in patients with osteonecrosis of the femoral head. AJR. American Journal of Roentgenology. 2006; 186 (6): 1761-70.

22. Perry T, O'Neill T, Parkes M, Felson DT, Hodgson R, Arden NK. Bone marrow lesion type and pain in knee osteoarthritis. Ann Rheum Dis. 2018; (77): 1145.

23. Tanamas SK, Wluka AE, Pelletier JP, Pelletier JM, Abram F, Berry $\mathrm{PA}$, et al. Bone marrow lesions in people with knee osteoarthritis predict progression of disease and joint replacement. A longitudinal study Rheumatology. 2010; (49): 2413-19.

24. Berger CE, Kroner AH, Minai-Pour MB, Ogris E, Engel A. Biochemical markers of bone metabolism in bone marrow edema syndrome of the hip. Bone. 2003; (33): 346-51.

25. Kuttapitiya A, Assi L, Laing K, Hing C, Mitchell P, Whitley G, et al. Microarray analysis of bone marrow lesions in osteoarthritis demonstrates upregulation of genes implicated in osteochondral turnover, neurogenesis and inflammation. Ann Rheum Dis. 2017; 76 (10): 1764-73.

26. Astur DC, de Freitas EV, Cabral PB, Morais CC, Pavei BS, Kaleka CC, et al. Evaluation and management of subchondral calcium phosphate injection technique to treat bone marrow lesion Cartilage. 2018; (10): 1177.

27. Su K, Bai Y, Wang J, Zhang H, Liu H, Ma S. Comparison of hyaluronic acid and PRP intra-articular injection with combined intra-articular and intraosseous PRP injections to treat patients with knee osteoarthritis. 2018; (37): 1341-50.

28. Fiz N, Pérez JC, Guadilla J, Garate A, Sánchez P, Padilla S, et al. Intraosseous Infiltration of Platelet-Rich Plasma for Severe Hip Osteoarthritis. 2017; 19 (6): 821-5.

29. Sánchez M, Anitua E, Delgado D, Sanchez P, Prado R, Goiriena JJ, et al. A new strategy to tackle severe knee osteoarthritis: Combination of intra-articular and intraosseous injections of Platelet Rich Plasma. Expert Opinion on Biological Therapy. 2016; (10): 15-7.

30. Kellgren JH, JeVrey M, Ball J. Atlas of standard radiographs. Vol 2. Oxford: Blackwell Scientific, 1963.

31. Roos E, Lohmander L. The Knee injury and Osteoarthritis Outcome Score (KOOS): from joint injury to osteoarthritis. Health and Quality of Life Outcomes. 2003; 1 (1): 64-72.

32. Marot V, Murgier J, Carrozzo A, Reina N, Monaco E, Chiron P et al. Determination of normal KOOS and WOMAC values in a healthy population. Knee Surgery, Sports Traumatology, Arthroscopy. 2018; 27 (2): 541-8.

33. Hawker G, Mian S, Kendzerska T, French M. Measures of adult pain: Visual Analog Scale for Pain (VAS Pain), Numeric Rating Scale for Pain (NRS Pain), McGill Pain Questionnaire (MPQ), Short-Form McGill Pain Questionnaire (SF-MPQ), Chronic Pain Grade Scale (CPGS), Short Form-36 Bodily Pain Scale (SF. Arthritis Care \& Research. 2011; 63 (S11): S240-52. 